\title{
Studium przypadku sieci międzyorganizacyjnej w sektorze dóbr i ustug środowiskowych
}

\author{
Dr inż. Adam Sulich iD \\ Uniwersytet Ekonomiczny we Wrocławiu \\ Wydział Zarządzania
}

\section{Wprowadzenie}

Problemy związane z ochroną środowiska naturalnego już wiele lat temu przestały być wyłączną domeną nauk ekologicznych, o czym świadczy sformułowana w latach osiemdziesiątych XX wieku interdyscyplinarna koncepcja zrównoważonego rozwoju ${ }^{1}$. Idea ta pozwoliła na podjęcie szeroko zakrojonych badań, a także na poszukiwanie specyficznych rozwiązań problemów przedstawionych na konferencji w Rio de Janeiro w 1992 roku i na następnych „Szczytach Ziemi”2. W ciągu kolejnych lat pojawiły się nowe wyzwania, a pewne niekorzystne zjawiska się pogłębiły ${ }^{3}$. Wśród nich na szczególną uwagę zasługują między innymi: różnice w dystrybucji dóbr między grupami społecznymi oraz krajami, spadek bioróżnorodności, malejące zasoby obszarów rolniczych, kurczące się zasoby słodkiej wody, wzrost poziomu wód oceanicznych oraz postępujące zanieczyszczenie mórz i oceanów. Należy przy tym zauważyć, że w latach osiemdziesiątych istotne problemy zrównoważonego rozwoju dotyczyły głównie środowiska naturalnego, a następnie stały się również problemami ekonomicznymi i społecznymi ${ }^{4}$.

1 G. Brundlandt, Report of the World Commission on Environment and Development: Our Common Future, Oslo 1987, http://www.un-documents.net/our-common-future.pdf (dostęp: 3.06.2020).

2 J. Murphy, D. Drexhage, Sustainable Development: From Brundtland to Rio 2012, United Nations Headquarters, New York 2010.

3 A. Merino-Saum i wsp., Articulating natural resources and sustainable development goals through green economy indicators: A systematic analysis, „Resources, Conservation and Recycling" 2018, no. 139.

4 A. Merino-Saum i wsp., Unpacking the Green Economy concept: A quantitative analysis of 140 definitions, „Journal of Cleaner Production” 2020, no. 242, https://doi.org/10.1016/j.jclepro .2019.118339 (dostęp: 3.06.2020). 
Koncepcja zrównoważonego rozwoju w naukach społecznych, szczególnie zaś w naukach ekonomicznych i naukach o zarządzaniu, zaowocowała wytyczeniem teoretycznych założeń i definicji dla tzw. zielonej gospodarki ${ }^{5}$ i zielonych miejsc pracy $^{6}$. Ponadto doszło do ekologizacji wielu dziedzin nauki, tj. przeniesienia akademickiej dyskusji na grunt wdrażanych rozwiązań w praktyce technologicznej i gospodarczej7, a także do opracowania strategii i wsparcia działań administracji publicznej ${ }^{8}$. Na podstawie zasad zrównoważonego rozwoju powstały również nowe definicje i klasyfikacje działalności gospodarczej, które wyodrębniły sektor dóbr i usług środowiskowych ${ }^{9}$. Ekologizacja zarządzania to również koncentracja działań na rozwiązywaniu w sposób pośredni lub bezpośredni problemów środowiska naturalnego i wyzwań ekologicznych (np. zarządzanie ograniczonymi zasobami lub wdrożenie dedykowanych patentów). Pomimo tak licznych, a nawet spektakularnych działań praktycznych, stosunkowo niedawno zrozumiano, jak znaczące dla ich powodzenia są zarządzanie i ich organizacja. Pozwalają one przenosić idee związane ze zrównoważonym rozwojem z wymiaru teoretycznego i skali globalnej do praktyki i skali bliższej10. W tym kontekście wymagane jest rozwinięcie opisu zależności występujących w zbiorowości gospodarczej dotychczas opisywanymi terminami ekologicznymi ${ }^{11}$. Nauki o zarządzaniu i organizacji, podejmując problematykę zrównoważonego rozwoju, stawiają sobie za cel zbadanie relacji występujących między organizacjami ${ }^{12}$. Ekologia organizacji to nauka, która ma na celu wzbogacanie wiedzy o oddziaływaniach i podstawowych więzach, jakie organizacje utrzymują ze środowiskiem, mogącym stanowić dla nich zarówno źródło wsparcia, jak i trudności ${ }^{13}$.

5 B. Ryszawska, Zielona gospodarka - teoretyczne podstawy koncepcji i pomiar jej wdrażania w Unii Europejskiej, Wydawnictwo Uniwersytetu Ekonomicznego we Wrocławiu, Wrocław 2013.

6 B. Kryk, Czas na zielone kotnierzyki, „Ekonomia i Środowisko” 2014, t. 3(50), s. 10-20.

7 A. Sulich, Rola zielonego zarzadzania w równoważeniu rynku pracy, praca doktorska, Politechnika Wroctawska, Wrocław 2019.

8 A. Sobol, Uwarunkowania rozwoju rynku dóbri usług ekologicznych w gminach województwa ślaskiego, „Studia Ekonomiczne. Zeszyty Naukowe Uniwersytetu Ekonomicznego w Katowicach" 2015, nr 232, s. 225-236, http://bazekon.icm.edu.pl/bazekon/element/bwmeta1 .element.ekon-element-000171396763 (dostęp: 3.06.2020).

9 E. Lorek (red.), Rozwój rynku dóbr i ustug ekologicznych w regionie śląskim, Wydawnictwo Akademii Ekonomicznej w Katowicach, Katowice 2002.

10 A. Sobol, Uwarunkowania rozwoju... s. 225.

11 S. Stańczyk, Tożsamość ekosystemu biznesu, Wydawnictwo Uniwersytetu Ekonomicznego we Wroctawiu, Wroctaw 2018.

12 J. Niemczyk, E. Stańczyk-Hugiet, Cooperative and competitive relationships in high education sector in Poland, „Journal of Economics Management” 2014, no. 17, s. 5-23.

13 G. Nizard, Metamorfozy przedsiębiorstwa. Zarzqdzanie w zmiennym otoczeniu organizacji, Wydawnictwo Naukowe PWN, Warszawa 1998. 
Celem opracowania jest przedstawianie przypadku sieci międzyorganizacyjnej funkcjonującej w sektorze dóbr i usług środowiskowych (Environmental Goods and Services Sector - EGSS) w kontekście teorii ekosystemu biznesu ${ }^{14}$. Tak przedstawionemu celowi podporządkowano strukturę pracy, która obejmuje kolejno: przedstawienie problemu relacji w sieci międzyorganizacyjnej biznesu przez metafory i analogie z naukami biologicznymi, charakterystykę sektora dóbr i usług środowiskowych, znaczenie zarządzania i organizacji dla procesów prowadzonych w opisanym sektorze, istotę sieci międzyorganizacyjnej, ilustracyjne studium przypadku sieci, której celem jest koordynacja działań w zakresie recyklingu, odzysku i utylizacji opon.

Szerokie badania populacji organizacji w zakresie ich relacji o charakterze eksploracyjnym mogą pomóc w przyszłości w ujawnieniu przyczyn ich złożoności, leżących w cechach ekosystemów, takich jak emergencja, samoregulacja, koewolucja i koadaptacja15. Dlatego praca ma charakter założeń teoretycznych i operacjonalizacji pojęć dla badania empirycznego, które będzie kontynuacją prowadzonego projektu. Przyjętą w pracy metodą jest abdukcyjne rozumowanie wyjaśniające ${ }^{16}$.

\section{Przedstawienie problemu}

Dowodem na ekologizację nauk o zarządzaniu jest teoria ekosystemu biznesu, która jest metaforą bezpośrednio zaczerpniętą z teorii ekologii ${ }^{17}$. Dlatego ekosystem biznesu definiuje się przez dynamiczny układ organizacji (biocenoza) połączonych ze sobą relacjami wraz ze środowiskiem gospodarczym (biotop), które zajmuje $^{18}$. W środowisku naturalnym relacje między organizmami mają charakter pokarmowy (troficzny), a zależności neutralne nie występują między nimi (oznaczają brak relacji). Relacje troficzne definiują różne sieci pokarmowe w obrębie ekosystemu. Analogicznie jest w przypadku ekosystemu biznesu. Otoczenie organizacji, „z racji swej ambiwalentnej istoty, stanowi zarówno zagrożenie dla przetrwania, jak i okazję do rozwoju"19. Istnienie organizacji jest możliwe jedynie w ekosystemie, „w związku ekologicznym, czyli przez swoje otoczenie oraz

14 S. Stańczyk, Tożsamość ekosystemu...

15 Tamże.

16 U. Wirth, Abductive reasoning in Peirce's and Davidson's account of interpretation, „Semiotica" 2005, vol. 153, no. 1/4, s. 199-208, https://doi.org/10.1515/semi.2005.2005.153-1-4.199 (dostęp: 2.06.2020).

17 S. Stańczyk, Tożsamość ekosystemu..., s. 64.

18 Tamże.

19 G. Nizard, Metamorfozy przedsiębiorstwa..., s. 7. 
w uzależnieniu od niego"20. Otoczenie jest czynnikiem zasilającym o wielkim stopniu zróżnicowania i wielorakich kombinacjach powiązań, dającym organizacjom niezbędną przestrzeń życiową. W przeciwieństwie do zasad panujących w ekosystemach naturalnych we współczesnej gospodarce organizacje często wybierają współpracę, czyli „działanie z innymi, w sytuacji, gdy co najmniej dwa podmioty mają wzajemnie dopełniające się cele" 21 . Zdaniem wielu autorów pozytywne oddziaływania i współdziałanie są podstawą relacji podmiotów przede wszystkim w sieciach międzyorganizacyjnych ${ }^{22}$. Ponadto powodzenie realizacji tak ambitnych i długofalowych przedsięwzięć związanych z koncepcją zrównoważonego rozwoju zależy, jak się wydaje, od pozytywnych relacji między podmiotami, współpracy i efektu synergii ${ }^{23}$. Współdziałanie jest zatem podstawą formowania sieci międzyorganizacyjnej, w której również może dochodzić do wielu różnych i nie do końca zdefiniowanych relacji ${ }^{24}$.

O ile można [...] dostrzec duży wkład badaczy nauk o zarządzaniu w zrozumienie istoty i natury sieci biznesowych, o tyle wciąż dostrzega się niedostatek teoretycznych i empirycznych opracowań, które pozwoliłyby na zrozumienie ich sieciowej struktury oraz relacji, jakie je współtworzą ${ }^{25}$.

Problematyka relacji między sieciami w tak zróżnicowanym sektorze, jakim jest sektor dóbr i usług środowiskowych, jest tematem nowym, dotychczas niepodejmowanym w literaturze nauk o zarządzaniu. Co więcej, podmioty skoncentrowane wokół wymiany jednego dobra lub usługi ekologicznej mogą mieć różne relacje (pozytywne lub negatywne) z podmiotami odrębnej sieci, na przykład

20 Tamże, s. 7.

21 B. Jasiński, Klasyfikacje sieci międzyorganizacyjnych, [w:] J. Niemczyk i wsp. (red.), Sieci międzyorganizacyjne. Wspótczesne wyzwanie dla teorii i praktyki zarzq̨dzania, Wydawnictwo C.H. Beck, Warszawa 2012, s. 101.

22 J. Niemczyk, B. Jasiński, Wstęp, [w:] J. Niemczyk, E. Stańczyk-Hugiet, B. Jasiński (red.), Sieci międzyorganizacyjne. Wspótczesne wyzwanie dla teorii i praktyki zarzq̨dzania, Wydawnictwo C.H. Beck, Warszawa 2012, s. 12.

23 H. Häkansson, J. Johanson, The Network as a Governance Structure: Interfirm Cooperation Beyond Markets and Hierarchies, [w:] G. Grabher (red.), The Embeded Firm. The Socio-Economics of Industrial Networks, Routledge, London 1993, s. 35; A. Sobol, Uwarunkowania rozwoju...

24 E. Stańczyk-Hugiet, Charakterystyka relacji, [w:] J. Niemczyk, E. Stańczyk-Hugiet, B. Jasiński (red.), Sieci międzyorganizacyjne. Wspótczesne wyzwanie dla teorii i praktyki zarzq̨dzania, Wydawnictwo C.H. Beck, Warszawa 2012, s. 32; T. Zema, A. Sulich, Relations in The Interorganizational Networks, vol. 6, 4th International Business Administrative Sciences Student Conference - IBASSC 2019, Erbil, Irak 2019.

25 S. Stańczyk, Tożsamość ekosystemu..., s. 9. 
administracji publicznej, która również swoimi kompetencjami przynależy do sektora dóbr i usług ekologicznych. Pewne złożone relacje między sieciami międzyorganizacyjnymi „wiążą ze sobą to, co pozornie wydaje się odległe od siebie”26. Dlatego podejście ekologiczne stara się zawsze wyjaśnić związki między organizacjami a ich otoczeniem, w myśl zasad: pojęcia współzależności, odwracalności przyczyn i skutków oraz ewolucji sprzężonych ze sobą zjawisk. Organizacja, która tworzy z innymi sieć międzyorganizacyjną, podobnie jak żywy organizm, czerpie z otoczenia i podlega jego wpływom, ale również oddziałuje sama na to środowisko, co widać szczególnie w sektorze dóbr i usług środowiskowych.

Transformacja gospodarki w kierunku zrównoważonej, zielonej gospodarki ${ }^{27}$ wymaga działań w zakresie zielonego zarządzania ${ }^{28}$, zarządzania środowiskowego oraz zarządzania środowiskiem ${ }^{29}$. Działania te prowadzą nie tylko do zmniejszenia antropopresji, ale również do tworzenia zielonych miejsc pracy ${ }^{30}$, co jest również przejawem ekologizacji zarządzania. Wymaga to od kierownictwa kompleksowej diagnozy zmiennych, zjawisk i procesów zachodzących w wielowymiarowym układzie gospodarka - społeczeństwo - środowisko ${ }^{31}$. Tym działaniom mogą towarzyszyć takie zachowania wobec innych podmiotów gospodarczych, które obejmują działania antagonistyczne, neutralne i nieantagonistyczne ${ }^{32}$. Nie jest jednak jednoznaczne, że działania antagonistyczne wobec pewnych zbiorowości podmiotów gospodarczych nie pociągają za sobą działań pozytywnych lub co najmniej nieantagonistycznych wobec innych członków ekosystemu biznesowego w obrębie sektora.

26 G. Nizard, Metamorfozy przedsiębiorstwa..., s. 8.

27 B. Ryszawska, Zielona gospodarka...

28 H. Lorek, M. Sonnenschein, Modelling and simulation software to support individual-based ecological modelling, „Ecological Modelling” 1999, no 115, s. 199-216; A. Sulich, Rola zielonego zarzadzania...

29 A. Sulich, Rola zielonego zarządzania...

30 A. Sulich, T. Zema, Green jobs, a new measure of public management and sustainable development, „European Journal of Environmental Sciences” 2018, vol. 8(1), s. 69-75.

31 A. Kasztelan, Green Competitiveness of the EU Countries, [w:] E. Kovár̆ová, L. Melecký, M. Staníčková (red.), Proceedings of the 3rd International Conference on European Integration 2016, VŠB - Technical University of Ostrava, Ostrava 2016, s. 415-424; A. Sobol, Uwarunkowania rozwoju..., s. 226.

32 S. Stańczyk, Tożsamość ekosystemu... 


\section{Sektor dóbr i ustug środowiskowych}

Pojęciem sektora dóbr i usług środowiskowych (Enviornmental Goods and Services Sector - EGSS) posługują się w swoich dokumentach Komisja Europejska i Eurostat. Definiują one ten sektor jako obejmujący różnorodnych producentów dóbr i usług, których celem jest ochrona środowiska naturalnego i zarządzanie jego zasobami ${ }^{33}$. Co więcej, oprócz samej definicji sektora Eurostat podaje definicję usług i dóbr środowiskowych, którymi są produkty wytwarzane lub usługi świadczone w celu ${ }^{34}$ :

- ograniczenia lub zapobiegania zanieczyszczeniom, degradacji lub wyczerpywaniu zasobów naturalnych;

- przywracania pierwotnego stanu powietrzu, wodzie, różnorodności biologicznej i krajobrazom, redukcji odpadów i hałasu;

- ograniczania, eliminowania, naprawy i zarządzania zanieczyszczeniami, degradacją i wyczerpywaniem zasobów naturalnych;

- prowadzenia innych działań, takich jak pomiary i monitorowanie, kontrola, badania i rozwój, edukacja, szkolenia, informacja i komunikacja związana z ochroną środowiska lub zarządzaniem zasobami.

Przedstawiona definicja dóbr i usług ekologicznych jest szeroka i uznaje za ekologiczne te dobra i usługi (z puli wszystkich dostępnych na rynku dóbr i usług), których:

[...] sposoby produkcji, dystrybucji, konsumpcji mają lub mogą mieć istotny, pozytywny lub obojętny wpływ na funkcjonowanie ekosystemów oraz zdrowie populacji ludzkich, jak również na wartości estetyczne krajobrazu i elementy unikatowe przyrody ${ }^{35}$.

Całkowite wyeliminowanie wytwarzania zanieczyszczeń i odpadów produkcyjnych i konsumpcji powodujących antropopresję jest niemożliwe, co sprawia, że nie istnieją wyłącznie produkty lub usługi całkowicie obojętne lub pozytywnie oddziałujące na środowisko naturalne ${ }^{36}$. Czasem od skali ich zastosowania zależy to, czy będą miały one charakter antyekologiczny ${ }^{37}$, co warto rozważyć w przypadku

33 Eurostat, Glossary: Environmental goods and services sector (EGSS), Eurostat Statistics Explained, 2018, https://ec.europa.eu/eurostat/statistics-explained/index.php/Glossary: Environmental_goods_and_services_sector_(EGSS) (dostęp: 4.01.2020).

34 Tamże.

35 E. Lorek (red.), Rozwój rynku dóbr i usług..., s. 14.

36 B. Ryszawska, Zielona gospodarka...

37 S. Khall Khalid, Create Shared Value, as a New Competitive Advantage, and its Impact on Sustainable Strategy Analytical Study Applied on a Sample of Hotels in Erbil City, [w:] Proceedings 
materiałów eksploatacyjnych między innymi dla przemysłu samochodowego, które będą powstawać niezależnie od tego, czy samochody będą elektryczne, czy zasilane kopalinami. Dlatego ze względu na techniki produkcji, użytkowania lub końcowej utylizacji można wyróżnić produkty i usługi ${ }^{38}$ :

- proekologiczne - związane z nowymi technikami pozwalającymi na zmniejszenie presji środowiskowej;

- ekologicznie obojętne - związane z technikami, które przy aktualnej skali zastosowania powodują antropopresję mieszczącą się w ramach zdolności środowiska do ich asymilacji ${ }^{39}$;

- antyekologiczne - związane głównie ze starymi technikami, charakterystycznymi dla brązowej gospodarki ${ }^{40}$, powodującymi duże presje środowiskowe, a które można usprawniać, zazieleniając gospodarkę ${ }^{41}$, lub modyfikować, tworząc ekoinnowacje ${ }^{42}$.

Sektor dóbr i usług środowiskowych w Polsce rozwija się głównie w zakresie usług publicznych i gospodarki komunalnej. Co więcej, „gospodarka komunalna jest tą sferą życia społeczno-gospodarczego, w której w ostatnich latach dokonuje się w Polsce radykalna transformacja"43. Sektor publiczny tworzą organy państwowe i samorządu terytorialnego, dla których najważniejszym celem jest zaspokojenie potrzeb osób mieszkających na terenie danego państwa lub regionu przez dostarczanie publicznych dóbr czystych (np. ład prawno-instytucjonalny) i dóbr mieszanych (np. ochrona środowiska, której celem jest zapewnienie ładu środowiskowego i ochrony zasobów naturalnych, zgodnie z koncepcją zrównoważonego rozwoju).

Book of International Conference on Accounting, Business, Economics and Politics, ICABEP 2019, Tishk International University in Erbil, Erbil, Kurdistan Region of Iraq 2019, s. 402-413.

38 A. Lorek, E. Lorek, Problemy rynku dóbr i usług ekologicznych, [w:] E. Lorek (red.), Rozwój rynku dóbri usług ekologicznych w regionie ślq̨skim, Wydawnictwo Akademii Ekonomicznej w Katowicach, Katowice 2002, s. 119.

39 Z. Dokurno, Równowaga ekologiczna w agregatowych modelach wzrostu gospodarczego jako fundamentalny czynnik realizacji strategii ekorozwoju, „Prace Naukowe Akademii Ekonomicznej we Wroctawiu" 2006, nr 5(1115), s. 95-106.

40 A. Sulich, T. Zema, Green jobs...

41 A. Grudziński, Wybrane narzędzia usprawniające proces zazieleniania gospodarki, „Rynek, Społeczeństwo, Kultura" 2018, nr 4, s. 39-43, http://www.kwartalnikrsk.pl/assets/rsk-42018-grudzinski-wybrane-narzedzia-usprawniajace-proces-zazielenienia-gospodarki.pdf (dostęp: 2.01.2020).

42 M. Rutkowska, Zielone miejsca pracy jako ecoinnowacja, „Zeszyt Naukowy Wyższej Szkoły Zarządzania i Bankowości w Krakowie" 2016, nr 39, s. 151-161, , http://bazekon.icm.edu.pl /bazekon/element/bwmeta1.element.ekon-element-000171433926 (dostęp: 2.06.2020).

43 A. Sobol, Uwarunkowania rozwoju..., s. 226. 
O sukcesie w transformacji w stronę zielonej gospodarki decydują połączone wysiłki polityków (samorządowców), mieszkańców (konsumentów) oraz szeroko rozumianego sektora podmiotów i instytucji ochrony środowiska. Dzieje się tak dlatego, że w Polsce głównym kierunkiem procesu przemian są działania na rzecz ochrony środowiska, czemu służy większość prowadzonych inwestycji i zmian organizacyjnych ${ }^{44}$. Co więcej, w praktyce gospodarczej omawia się bardzo konkretnie zapisane typy powiązań sieciowych. Chrisidu-Budnik wymienia przykłady tego typu umów:

- holding, który stanowi formę integracji gospodarczej polegającą na funkcjonowaniu w ramach jednej struktury gospodarczej wielu niezależnych prawnie podmiotów, powiązanych relacjami dominacji i zależności,

- alianse strategiczne/umowy o wspólne przedsięwzięcie (joint-ventures) - umowa konsorcjum, umowa joint-venture, umowa o współpracę gospodarczą, które są formą kooperacji odrębnych podmiotów, pozostającą bez wpływu na ich byt prawny lub skład wspólników/akcjonariuszy,

- partnerstwo publiczno-prywatne, w Polsce realizowane w oparciu o spółkę komandytową, komandytowo-akcyjną i spółki kapitałowe,

- pozostałe umowy nazwane i nienazwane (umowa o dzieło, agencyjna, franchisingowa, itp.), jak i formy współdziałania przewidziane przez prawo administracyjne ${ }^{45}$.

Koncepcja zielonej gospodarki ${ }^{46}$ prowadzi do tworzenia zielonego rynku pracy, który jest następstwem rynku dóbr i usług środowiskowych. Rynek ten funkcjonuje w obrębie procesów gospodarowania, obejmujących sferę realną i regulacyjną. Natomiast podstawowymi podmiotami tego rynku są:

- środowisko naturalne - źródło surowców i energii;

- konsumenci (gospodarstwa domowe);

- podmioty gospodarcze;

- producenci (przedsiębiorstwa przemysłowe, gospodarstwa rolne, warsztaty rzemieślnicze);

- przedsiębiorstwa usługowe, przedsiębiorstwa handlowe;

- instytucje finansowe;

- państwo.

44 Tamże.

45 A. Chrisidu-Budnik, Elementy sieci - aspekty prawne, [w:] J. Niemczyk, E. Stańczyk-Hugiet, B. Jasiński (red.), Sieci międzyorganizacyjne. Wspótczesne wyzwanie dla teorii i praktyki zarządzania, Wydawnictwo C.H. Beck, Warszawa 2012, s. 45.

46 B. Ryszawska, Zielona gospodarka...; A. Sulich, Rola zielonego zarządzania... 
Państwo i jego administracja to składniki sfery regulującej przebieg procesów materialno-rzeczowych. Państwo - przez systemy przepisów prawnych - ma istotny wpływ na procesy gospodarcze. Szczegółowe relacje między podmiotami rynku dóbr i usług przedstawiono na rysunku 1.

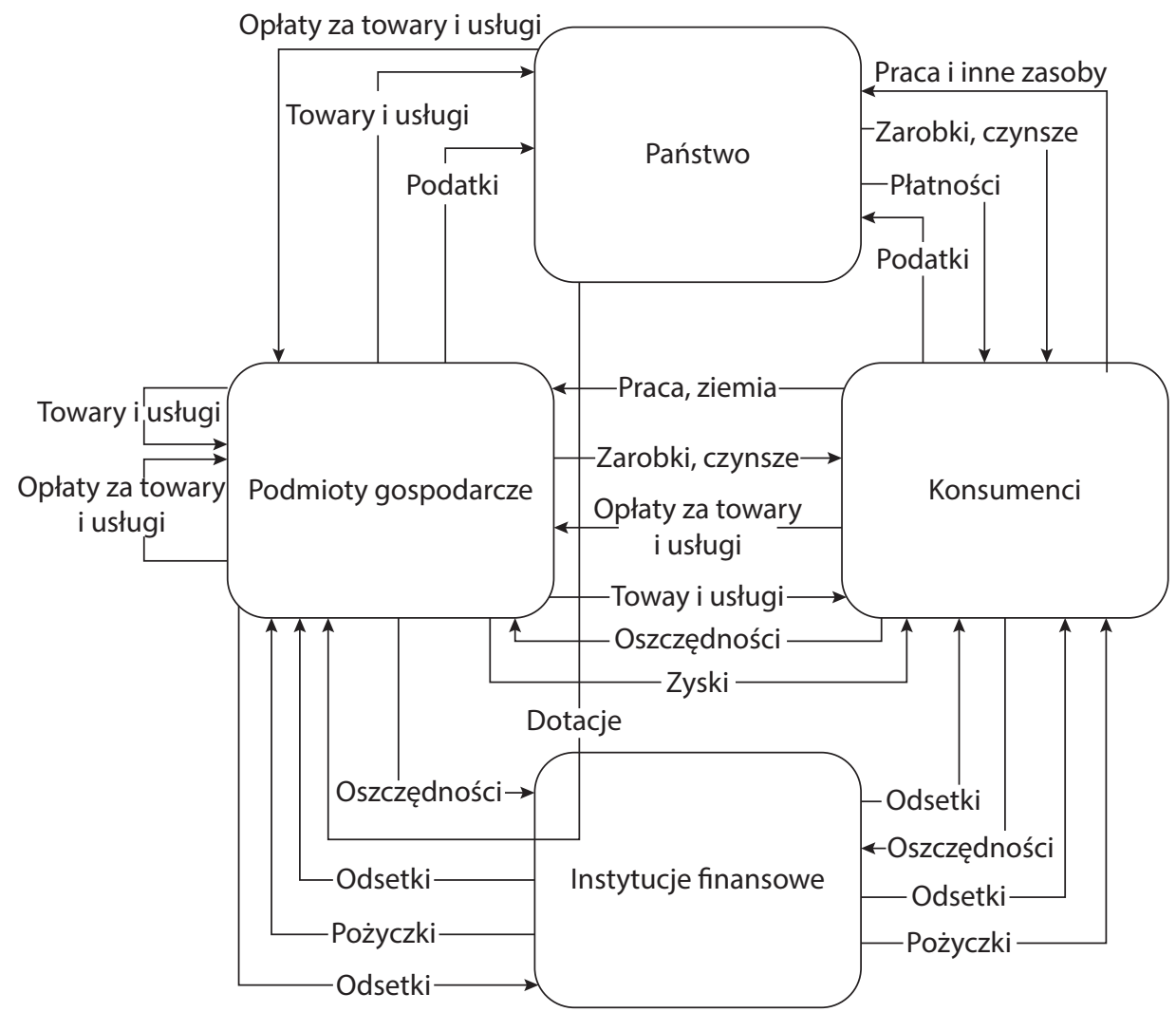

Rysunek 1. Schemat funkcjonowania rynku dóbr i usług środowiskowych

Źródto: A. Lorek, E. Lorek, Problemy rynku dóbr i ustug ekologicznych, [w:] E. Lorek (red.), Rozwój rynku dóbr i usług ekologicznych w regionie ślqaskim, Wydawnictwo Akademii Ekonomicznej w Katowicach, Katowice 2002, s. 120.

Wydawanie aktów normatywnych (zarządzanie środowiskiem), rola moderatora rynku i reprezentacja środowiska przyrodniczego artykułującego na rynku preferencje środowiska (zarządzanie środowiskowe) są ważnymi zadaniami państwa ${ }^{47}$.

47 T. Ponomarenko i wsp., Formation of the investment environment in Ukraine in the context of European integration: An example of Poland, „Investment Management and Financial Innovations" 2018, vol. 15(1), s. 361-373. 
Jednak aktualna polityka państwa oraz związane z nią regulacje prawne stanowią transpozycję przepisów wspólnotowych Unii Europejskiej ${ }^{48}$.

Warunkiem włączenia zasobów środowiska przyrodniczego w gospodarcze mechanizmy rynkowe jest zaprzestanie postrzegania ich jako dóbr wolnych oraz ustanowienie podmiotu o kompetencjach właścicielskich. „Takim podmiotem powinien być organ władzy regionalnej, państwowej lub instytucja międzynarodowa"49.

\section{Rola zarządzania i organizacji}

Administracja publiczna w Polsce odpowiada za realizację większości usług realizowanych na rzecz społeczeństwa i środowiska. Państwo jest zatem nie tylko uczestnikiem (inwestorem, wykonawcą), ale również koordynatorem rynku dóbr i usług środowiskowych, zgodnie z założeniami zrównoważonego rozwoju (który jest zasadą konstytucyjną) zapewnia bezpieczeństwo środowisku, gospodarce i obywatelom. Ważną składową realizacji działań z zakresu zrównoważonego rozwoju jest planowanie przestrzenne i gospodarka komunalna ${ }^{50}$. W ten sposób cześć administracji publicznej na szczeblu samorządowym (gminnym) ma charakter obsługowy wobec mieszkańców ${ }^{51}$. Jakość obsługi mieszkańców poprawia się wskutek presji sektora prywatnego, dlatego zmiany w sektorze publicznym są widoczne głównie w obszarze gospodarki komunalnej ${ }^{52}$. Ponadto wiele spośród ustawowo określonych zadań gminy dotyczy usług związanych z rynkiem dóbr i usług ekologicznych ${ }^{53}$. Są nimi:

- zbiorowe dostarczanie wody;

- zbiorowe odprowadzanie i oczyszczanie ścieków komunalnych;

- gospodarka odpadami;

- ochrona powietrza;

- transport, utrzymanie dróg gminnych;

- ochrona i utrzymanie terenów zieleni;

- budownictwo ekologiczne;

- ochrona gleb, rekultywacja i rewitalizacja terenów poprzemysłowych;

- zabezpieczenie przeciwpowodziowe;

- edukacja ekologiczna;

48 A. Sobol, Uwarunkowania rozwoju..., s. 226.

49 A. Lorek, E. Lorek, Problemy rynku dóbr i usług..., s. 121.

50 A. Sobol, Uwarunkowania rozwoju..., s. 225.

51 D. Pawliszczy, Ewolucja i rola samorzqdu terytorialnego w Polsce, „Prace Naukowe Wyższej Szkoły Zarządzania i Przedsiębiorczości z siedzibą w Wałbrzychu” 2016, nr 38(2), s. 117-128.

52 Tamże; A. Sobol, Uwarunkowania rozwoju...

53 A. Sobol, Uwarunkowania rozwoju..., s. 230. 
- alternatywne źródła energii, poprawa efektywności energetycznej;

- ochrona przyrody i bioróżnorodności;

- ochrona przed hałasem;

- rolnictwo ekologiczne.

„Ekologizacja gospodarki komunalnej jest również wyrazem rosnącej świadomości ekologicznej mieszkańców"54. Na podstawie Ustawy z dnia 20 grudnia 1996 r. o gospodarce komunalnej (Dz.U. z 1997 r. Nr 9, poz. 43) gminy mogą tworzyć własne jednostki organizacyjne lub angażować podmioty zewnętrzne, które należą do sektora dóbr i usług środowiskowych.

Jednym z przejawów nowoczesnego podejścia do zarządzania jest orientacja na innowacje i ochronę środowiska. Szczególną rolę na rynku dóbr i usług ekologicznych pełnią ekoinnowacje, czyli „każda innowacja redukująca negatywne oddziaływanie na środowisko naturalne w całym cyklu życia produktu oraz zmniejszająca szkody w tym środowisku" 55. Na znaczeniu zyskują w tym przypadku zielone miejsca pracy, które również traktowane są jako ekoinnowacja, ponieważ „to rozwiązania problemów ekologicznych i gospodarczych, które stają się problemami zarówno społecznymi, jak też zarządczymi”56. Zielone miejsca pracy przenoszą na grunt praktyki gospodarczej teoretyczne założenia zrównoważonego rozwoju ${ }^{57}$. Komisja Europejska zielone miejsca pracy definiuje jako:

[...] wszelkie miejsca pracy zależne od środowiska naturalnego bądź stworzone, zamienione lub przekształcone (pod względem ekologizacji kwalifikacji, metod pracy, profilu stanowiska) w procesie przechodzenia w kierunku bardziej ekologicznej [zielonej] gospodarki ${ }^{58}$.

Dla wielu organizacji jednym z oczekiwanych rezultatów ekoinnowacji jest zwiększenie skuteczności ekologicznej - bezpośrednio przez poprawę wyników i parametrów środowiskowych, a pośrednio przez zwiększenie konkurencyjności ${ }^{59}$. Coraz szybsze tempo zmian technologicznych oraz skracanie cyklu życia

54 Tamże, s. 226.

55 A. Sobol, Uwarunkowania rozwoju..., s. 229.

56 A. Sulich, Rola zielonego zarzq̨dzania..., s. 4.

57 A. Grudziński, Wybrane narzędzia...; Ł. Kozar, „Zielone” miejsca pracy jako efekt dążeń do zrównoważonego rozwoju społeczno-gospodarczego, „Rynek - Społeczeństwo - Kultura" 2015, nr 3, s. 5-11.

58 A. Cox, B. Foley, Public Employment Services and Green Jobs, European Commission, Brussels 2013, s. 14, https://ec.europa.eu/social/BlobServlet?docld=14107langld=en (dostęp: 1.01.2020).

59 A. Sobol, Uwarunkowania rozwoju..., s. 229. 
produktów i technologii wymagają jednak ponoszenia coraz większych nakładów na badania ${ }^{60}$, rozwój i oczywiście wprowadzenia nowych produktów, ze zwiększonymi wymaganiami dotyczącymi ochrony środowiska i obsługi konsumenta.

\section{Sieć międzyorganizacyjna}

Rosnąca popularność sieci wśród badaczy z obszaru zarządzania jest spowodowana głównie dynamicznym rozwojem współdziałania sieciowego. Jest ono przede wszystkim „zorientowane na innowacyjność, czyli współdziałanie w sieci innowacji"61. Współdziałanie jest oddziaływaniem pozytywnym. Sieci oparte są głównie na wymianie materialnej i wzajemnie świadczonych usługach, uzupełnianych wymianą zasobów niematerialnych, „stanowiących siłę napędową procesu strategicznego mającego naturę procesu holistycznego"62. Czasem sieci te są odrębnymi strukturami, w których tworzona jest wartość dostarczana interesariuszom ${ }^{63}$. Oddziaływanie pozytywne występuje zatem wewnątrz sieci, natomiast między sieciami występuje pewna odrębność. Oddzielność ta oznacza, że różne sieci międzyorganizacyjne, skupione na zdefiniowanych własnych celach, mają w określonym sektorze nieantagonistyczne, neutralne oddziaływania (pozbawione relacji). W takim ujęciu sieci międzyorganizacyjne są traktowane jako źródło informacji, wiedzy oraz miejsce kreowania i wdrażania innowacji, na przykład zielonych miejsc pracy ${ }^{64}$. Zbiór wszystkich sieci i oddziaływań między sieciami tworzy ekosystem biznesowy sektora dóbr i usług środowiskowych.

Sieć międzyorganizacyjna to układ przynajmniej dwóch niezależnych i samodzielnych organizacji (diada), powiązanych ze sobą zbiorem więzi służących współdziałaniu. Sieć międzyorganizacyjna jest „układem złożonym z długookresowych, nieincydentalnych powiązań podmiotów zorientowanych na relację zbieżnych celów"65. W opisie sieci międzyorganizacyjnej, opartym na teorii grafów, organizacje tworzące sieć nazywane są węzłami lub wierzchołkami sieci (nodes). Natomiast „zorientowane na osiąganie wspólnych celów - długookresowe więzi”66 między nimi (więzi międzyorganizacyjne, powiązania) nazywane są krawędziami (edges). Zastosowanie teorii grafów pozwala prześledzić procesy zachodzące

60 B. Jasiński, Klasyfikacje sieci..., s. 103.

61 P. Klimas, Sieci innowacji. Implikacje bliskości organizacyjnej, Wydawnictwo Uniwersytetu Ekonomicznego w Katowicach, Katowice 2014, s. 7.

62 Tamże, s. 27.

63 Tamże.

64 M. Rutkowska, Zielone miejsca...

65 P. Klimas, Sieci innowacji..., s. 31.

66 Tamże. 
w sieci, włącznie z ustaleniem kierunku oddziaływań67. Co więcej, procesy związane z cyklem życia produktu mogą ujawnić istnienie sieci międzyorganizacyjnej lub jej elementy ${ }^{68}$. W przypadku sieci międzyorganizacyjnej w obrębie sektora dóbr i usług środowiskowych takim procesem jest postępowanie z odpadami, na przykład zużytymi oponami.

\section{Studium przypadku}

Wzrost liczby pojazdów pociąga za sobą nie tylko zanieczyszczenia powietrza, ale również wzrost liczby opon wprowadzanych na rynek. Opony, które zostają wycofane z eksploatacji, stanowią kłopotliwy w utylizacji odpad. Dlatego tak ważne jest wprowadzenie mechanizmów pozwalających je ponownie wykorzystać. Dotychczas opracowane technologie recyklingu odpadów pozwalają na coraz lepsze wykorzystanie zużytych opon, dzięki czemu stają się one cennym surowcem wtórnym. „Wciąż jednak pozostaje wiele problemów związanych z utylizacją ogumienia, nad którymi pracują zespoły naukowców z całego świata"69. Od 2012 roku w Polsce ustawowo zabrania się składowania opon i ich części na wysypiskach oraz składach. Co więcej, na składowiskach opon dochodzi coraz częściej do groźnych pożarów. U podstaw procesów technologicznych utylizacji opon leżą procesy zarządzania, a w szczególności te dotyczące logistyki odbioru tych odpadów z punktów usługowych (m.in. zakładów naprawy samochodów, zakładów wulkanizacyjnych) lub punktów zbiorczych zorganizowanych przez lokalny samorząd.

Rozpatrywanym przykładem sieci międzyorganizacyjnej w sektorze dóbr i usług środowiskowych jest sieć utworzona przez Centrum Utylizacji Opon Organizacja Odzysku S.A. (w skrócie CUO) wspólnie z producentami i przetwórcami opon, między innymi spółkami z Grupy Recykl S.A. i cementowaniami. Podmioty te tworzą sieć dedykowaną recyklingowi, przetwarzaniu i gospodarowaniu poużytkowymi odpadami, jakimi są opony. CUO jest spółką założoną przez największe podmioty produkujące opony na polskim rynku: Bridgestone, Continental, Dębica, GoodYear, Michelin i Pirelli, które jednocześnie pełnią funkcję udziałowców spółki. Celem działalności jest wykonywanie założeń Ustawy z dnia 11 maja 2001 r. o obowiązkach przedsiębiorców w zakresie gospodarowania niektórymi odpadami oraz o opłacie produktowej (Dz.U. z 2018 r., poz. 1932).

67 T. Zema, A. Sulich, Relations...

68 E. Stańczyk-Hugiet, J.M. Lichtarski, K. Piórkowska, The Dynamics of Inter-firm Relationships along the Industry Life Cycle: Theoretical Background and Conceptual Framework, „Transformations in Business Economics" 2019, no. 18(2B (47B)), s. 767-782.

69 Oponeo.pl, Recykling i drugie życie opon, 2019, https://www.oponeo.pl/artykul/recykling -opon (dostęp: 27.04.2020). 
Ustawa nakłada na producentów i importerów opon między innymi konieczność zebrania na terenie kraju i poddania odzyskowi masy odpadów po oponach nie mniejszej niż 75\% tonażu opon wprowadzonych przez nich na rynek w poprzednim roku kalendarzowym, z czego minimum $15 \%$ musi zostać poddane procesom recyklingu materiałowego ${ }^{70}$. W przeciwnym wypadku naliczana jest tzw. opłata produktowa, która zasila budżet właściwego urzędu marszałkowskiego ${ }^{71}$.

CUO zajmuje się kompleksowo całym procesem logistycznym, poczynając od nieodpłatnego odbioru zużytych opon od wszystkich podmiotów wskazanych przez klientów CUO jako uprawnione, poprzez segregowanie według typów, po transport do punktów, które poddają je odzyskowi (np. energetycznemu) lub recyklingowi materiałowemu. Jednocześnie spółka ułatwia wypełnianie przez przedsiębiorców z branży motoryzacyjnej obowiązków wynikających z przepisów o ochronie środowiska. Między innymi dzięki działalności CUO w ciągu kilku lat praktycznie zlikwidowany został problem dzikich wysypisk zużytych opon oraz ich nielegalnych składowisk. Centrum Utylizacji Opon Organizacja Odzysku S.A. jest również członkiem Europejskiego Stowarzyszenia Producentów Opon i Wyrobów Gumowych (ETRMA) ${ }^{72}$.

Tak więc oprócz wymiaru operacyjnego sieci, opierającego się na procesach recyklingu opon, sieć ma charakter koordynacyjno-nadzorczy, wspierany procesami i narzędziami informatycznymi, które pozwalają na zbieranie i opracowywanie danych z podległych podmiotów. Wykorzystanie infrastruktury informatycznej umożliwia koordynację węzłów sieci międzyorganizacyjnej oraz utrzymywanie relacji operacyjnych niezbędnych do realizacji celów sieci tworzonej przez CUO. Monitorowanie procesów operacyjnych w przedstawionej sieci to jeden z podstawowych mechanizmów towarzyszących procesom sektora dóbr i usług środowiskowych (rysunek 2).

Nadrzędnym zadaniem sieci tworzonej przez CUO jest rozwiązywanie problemu zużytych opon poprzez organizowanie ich odbioru od punktów wymiany opon i warsztatów samochodowych oraz poddanie ich procesom odzysku i recyklingu ${ }^{73}$. CUO prowadzi niektóre z procesów możliwych do realizacji w sektorze dóbr i usług środowiskowych (rysunek 2), są nimi przede wszystkim regeneracja i recykling. U podstaw tych procesów leży odbiór zużytych opon. Zbiórkę opon od mieszkańców może zorganizować samorząd gminny, który - jako podmiot administracji państwowej - powierzy CUO ich odbiór. W tym przypadku sieć międzyorganizacyjna

70 Tamże.

71 Tamże.

72 Centrum Utylizacji Opon Organizacja Odzysku, O nas. Centrum Utylizacji Opon, 2019, http:// utylizacjaopon.pl/CentrumUtylizacjiOpon (dostęp: 5.01.2020).

73 Tamże. 
współpracuje z podmiotami administracji publicznej różnego szczebla o charakterze kontrolnym i wykonawczym w celach sprawozdawczych, natomiast wzajemne świadczenie usług zachodzi na najniższym szczeblu samorządowym.

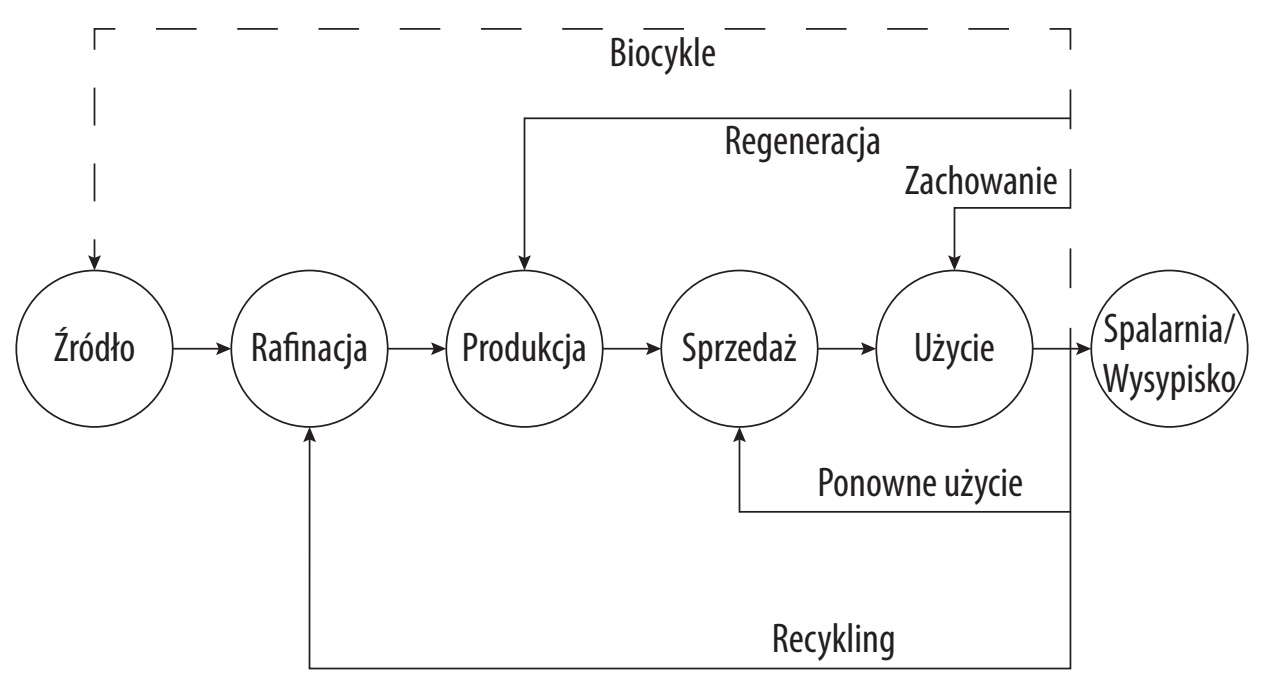

Rysunek 2. Procesy sektora dóbr i usług środowiskowych na tle cyklu życia produktu

Źródto: opracowanie własne na podstawie H. Friedl, „Circular Economy” - hacking a broken system while building a new future, TEDx Talks, 2018, https:// www.youtube.com/watch?v=_PKbUFJ3lu4 (dostęp: 4.04.2020).

Klienci indywidualni mogą zostawić opony w serwisie, w którym dokonują wymiany opon lub zawieźć je do zakładu wulkanizacyjnego. Brakuje jednak przepisów, które regulują kwestię opłat lub ich braku za przekazanie zużytych opon. Natomiast usługa odbioru opon w ilościach przemysłowych z tych punktów serwisowych i zakładów samochodowych, realizowana w kooperacji z Centrum Utylizacji Opon, jest bezpłatna, a cały dalszy proces jest odpowiednio udokumentowany na Kartach Przekazania Odpadów (KPO).

Grupa Recykl S.A. jest partnerem strategicznym CUO. W wyniku działania całej sieci międzyorganizacyjnej zużyte opony są przetwarzane, na przykład w mechanicznym procesie rozdrabniania (rafinacja), w wyniku czego uzyskuje się takie produkty jak:

- granulat gumowy - wykorzystywany głównie do wytwarzania powierzchni gumowanych (nawierzchnie placów zabaw i obiektów sportowych, progi zwalniające);

- chips - stosowany do współspalania z miałem węglowym oraz paliwami alternatywnymi w przemyśle cementowym;

- złom stalowy - wykorzystywany jako wsad w przemyśle hutniczym. 
Inne przedsiębiorstwa produkują ponadto gumową mączkę, która jest tańszym substytutem kauczuku i stanowi cenny surowiec wtórny dla przemysłu oponiarskiego $^{74}$. Zakłady oponiarskie tworzące CUO uczestniczą zatem w procesie recyklingu. Sieć pozwala na koordynację działań logistycznych i procesowych, których indywidualne przedsiębiorstwa nie mogłyby samodzielnie zrealizować.

W przedstawionej sieci nie dochodzi do przypadków konkurencji, ponieważ odpady przemysłu oponiarskiego nie są rzadkim surowcem wtórnym. Współpraca między podmiotami odzwierciedla proces recyklingu. Przetwarzanie odpadów w rozpatrywanej sieci to przede wszystkim spełnienie wymogu formalnego narzuconego przez administrację państwową (scentralizowana sieć hierarchiczna). Jednak przynależność do sieci to element prestiżu i budowania marki odpowiedzialnej (producenci opon). Odpady poużytkowe przemysłu samochodowego są najtrudniejszymi w recyklingu i będą powstawać niezależnie od źródła zasilania pojazdów samochodowych, dlatego tak istotne jest skuteczne funkcjonowanie sieci. Dzięki sieci, której działaniem koordynuje CUO, z każdym rokiem w Polsce recyklingowi poddawanych jest więcej opon, niż przewiduje to ustawa - na przykład w 2017 roku poziom odzyskiwanych zużytych opon wynosił 80,7\%, z czego do recyklingu materiałowego trafiło $35,4 \%{ }^{75}$.

\section{Podsumowanie}

Sieci międzyorganizacyjne są specyficzną formą wielopodmiotowego współdziałania, w której powiązania między podmiotami mają charakter więzi międzyorganizacyjnych ${ }^{76}$. Wewnątrz sektora dóbr i usług środowiskowych w przypadku dóbr i usług o charakterze informacji mają one znamiona „konstelacji wartości” (walor edukacyjny), natomiast w przypadku sieci opartych na działalności operacyjnej tworzą również „sieci wartości” (walor utylitarny). Działania poszczególnych podmiotów sieci mają charakter procesowy, służą poprawie stanu środowiska naturalnego. Rolą Centrum Utylizacji Opon Organizacja Odzysk S.A. jest koordynacja i nadzór nad procesami utrzymania, ponownego wykorzystania, powtórnej produkcji (remanufacturing) i wreszcie recyklingu oraz utylizacji opon w obrębie przedstawionej sieci. Oddziaływania między sieciami kontrolowane są przez administrację państwową, która „zgodnie z założeniami zrównoważonego

74 D. Majka, Biznes na łysych oponach, „Gazeta Wyborcza” 2011, http://wyborcza.biz/biznes /1,147584,10048960,Biznes_na_lysych_oponach.html?disableRedirects=true (dostęp: 2.02.2020).

75 Oponeo.pl, Recykling...

76 E. Stańczyk-Hugiet i wsp., Evolutionary Selection Processes. Towards Intra-Organizational Facets, Emerald Publishing, Bingley 2019. 
rozwoju dba o synergiczność aspektów ekonomicznych, społecznych i środowiskowych, a także zapewnia bezpieczeństwo zarówno człowiekowi, środowisku, jak i gospodarce"77.

Między zwierzchnią (nadrzędną) siecią administracji państwowej a analizowaną siecią recyklingu opon dochodzi do nieantagonistycznych (pozytywnych) relacji. W ich wyniku mogą powstać na przykład zielone miejsca pracy, to jest miejsca pracy pozytywnie oddziałujące na środowisko w wymiarze produktowym (usługowym) i procesowym. Co więcej, w obrębie sieci, której centrum (jest to zatem sieć scentralizowana) tworzy CUO, istnieje grupa przedsiębiorstw zaangażowanych w ciągłe rozbudowywanie sieci organizacyjnej, którą współtworzą. Ich zachowanie jest oparte nie tylko na relacjach niematerialnych (budowanie reputacji i marki), ale przede wszystkim na wymianie materialnych dóbr i towarzyszącym im usług oraz determinowane jest przez chęć własnego rozwoju (poszukiwanie nowych technik recyklingu opon). Pozytywnym aspektem działania sieci jest ponowne użycie znacznej ilości surowców wtórnych w produkcji opon oraz ograniczenie negatywnych skutków działania przemysłu oponiarskiego. Doświadczenia zdobyte we współdziałaniu w sieci międzyorganizacyjnej tworzonej przez CUO mogą zostać wykorzystane w innych sektorach gospodarki, w których regulacje prawno-administracyjne mogą stanowić wyzwanie dla indywidualnych przedsiębiorstw.

Projekt finansowany w ramach programu Narodowego Centrum Nauki pod nazwą. „Ekosystem Biznesu Sektora Dóbr i Usług Środowiskowych w Polsce”, realizowanego w latach 2020-2022 projektu nr 2019/33/N/HS4/02957, kwota finansowania 120 900,00 PLN.

\section{Bibliografia}

Brundlandt G., Report of the World Commission on Environment and Development: Our Common Future, Oslo 1987, http://www.un-documents.net/our-common-future.pdf (dostęp: 3.06.2020).

Centrum Utylizacji Opon Organizacja Odzysku, O nas. Centrum Utylizacji Opon, 2019, http://uty lizacjaopon.pl/CentrumUtylizacjiOpon (dostęp: 5.01.2020).

Chrisidu-Budnik A., Elementy sieci-aspekty prawne, [w:] J. Niemczyk, E. Stańczyk-Hugiet, B. Jasiński (red.), Sieci międzyorganizacyjne. Wspótczesne wyzwanie dla teorii i praktyki zarzqdzania, Wydawnictwo C.H. Beck, Warszawa 2012, s. 43-65.

Cox A., Foley B., Public Employment Services and Green Jobs, European Commission, Brussels 2013, https://ec.europa.eu/social/BlobServlet?docld=14107langld=en (dostęp: 1.01.2020).

Dokurno Z., Równowaga ekologiczna w agregatowych modelach wzrostu gospodarczego jako fundamentalny czynnik realizacji strategii ekorozwoju, „Prace Naukowe Akademii Ekonomicznej we Wrocławiu" 2006, nr 5(1115), s. 95-106.

77 A. Sobol, Uwarunkowania rozwoju..., s. 225. 
Eurostat, Glossary: Environmental goods and services sector (EGSS), Eurostat Statistics Explained, 2018, z https://ec.europa.eu/eurostat/statistics-explained/index.php/Glossary: Environmental_goods_and_services_sector_(EGSS) (dostęp: 4.01.2020).

Friedl H., "Circular Economy” - hacking a broken system while building a new future, TEDx Talks, 2018, https://www.youtube.com/watch?v=_PKbUFJ3lu4 (dostęp: 4.04.2020).

Grudziński A., Wybrane narzędzia usprawniajqce proces zazieleniania gospodarki, „Rynek, Spoteczeństwo, Kultura" 2018, nr 4, s. 39-43, http://www.kwartalnikrsk.pl/assets/rsk-4-2018 -grudzinski-wybrane-narzedzia-usprawniajace-proces-zazielenienia-gospodarki.pdf (dostęp: 2.01.2020).

Häkansson H., Johanson J., The Network as a Governance Structure: Interfirm Cooperation Beyond Markets and Hierarchies, [w:] G. Grabher (red.), The Embeded Firm. The Socio-Economics of Industrial Networks, Routledge, London 1993, s. 35-51.

Jasiński B., Klasyfikacje sieci międzyorganizacyjnych, [w:] J. Niemczyk, E. Stańczyk-Hugiet, B. Jasiński (red.), Sieci międzyorganizacyjne. Współczesne wyzwanie dla teorii i praktyki zarzqdzania, Wydawnictwo C.H. Beck, Warszawa 2012, s. 101-109.

Kasztelan A., Green Competitiveness of the EU Countries, [w:] E. Kovářová, L. Melecký, M. Staníčková (red.), Proceedings of the 3rd International Conference on European Integration 2016, VŠB - Technical University of Ostrava, Ostrava 2016, s. 415-424.

Khall Khalid S., Create Shared Value, as a New Competitive Advantage, and its Impact on Sustainable Strategy Analytical Study Applied on a Sample of Hotels in Erbil City, [w:] Proceedings Book of International Conference on Accounting, Business, Economics and Politics, ICABEP 2019, Tishk International University in Erbil, Erbil, Kurdistan Region of Iraq 2019, s. 402-413.

Klimas P., Sieci innowacji. Implikacje bliskości organizacyjnej, Wydawnictwo Uniwersytetu Ekonomicznego w Katowicach, Katowice 2014.

Kozar Ł., „Zielone” miejsca pracy jako efekt dążeń do zrównoważonego rozwoju społeczno-gospodarczego, „Rynek - Społeczeństwo - Kultura” 2015, nr 3, s. 5-11.

Kryk B., Czas na zielone kotnierzyki, „Ekonomia i Środowisko” 2014, t. 3(50), s. 10-20.

Lorek A., Lorek E., Problemy rynku dóbr i ustug ekologicznych, [w:] E. Lorek (red.), Rozwój rynku dóbri usług ekologicznych w regionie ślq̨skim, Wydawnictwo Akademii Ekonomicznej w Katowicach, Katowice 2002, s. 117-121.

Lorek H., Sonnenschein M., Modelling and simulation software to support individual-based ecological modelling, „Ecological Modelling” 1999, no 115, s. 199-216.

Lorek E. (red.), Rozwój rynku dóbr i usług ekologicznych w regionie ślq̨skim, Wydawnictwo Akademii Ekonomicznej w Katowicach, Katowice 2002.

Majka D., Biznes na tysych oponach, „Gazeta Wyborcza” 2011, http://wyborcza.biz/biznes/1,1475 84,10048960,Biznes_na_lysych_oponach.html?disableRedirects=true (dostęp: 2.02.2020).

Merino-Saum A., Baldi M.G., Gunderson I., Oberle B., Articulating natural resources and sustainable development goals through green economy indicators: A systematic analysis, „Resources, Conservation and Recycling" 2018, no. 139, s. 90-103.

Merino-Saum A., Clement J., Wyss R., Baldi M.G., Unpacking the Green Economy concept: A quantitative analysis of 140 definitions, „Journal of Cleaner Production” 2020, no. 242, https:// doi.org/10.1016/j.jclepro.2019.118339 (dostęp: 3.06.2020).

Murphy J., Drexhage D., Sustainable Development: From Brundtland to Rio 2012, United Nations Headquarters, New York 2010.

Niemczyk J., Jasiński B., Wstęp, [w:] J. Niemczyk, E. Stańczyk-Hugiet, B. Jasiński (red.), Sieci międzyorganizacyjne. Wspótczesne wyzwanie dla teorii i praktyki zarzq̨dzania, Wydawnictwo C.H. Beck, Warszawa 2012, s. 9-15.

Niemczyk J., Stańczyk-Hugiet E., Cooperative and competitive relationships in high education sector in Poland, „Journal of Economics and Management” 2014, no. 17, s. 5-23. 
Nizard G., Metamorfozy przedsiębiorstwa. Zarzq̨dzanie w zmiennym otoczeniu organizacji, Wydawnictwo Naukowe PWN, Warszawa 1998.

Oponeo.pl, Recykling i drugie życie opon, 2019, https://www.oponeo.pl/artykul/recykling-opon (dostęp: 27.04.2020).

Pawliszczy D., Ewolucja i rola samorzq̨du terytorialnego w Polsce, „Prace Naukowe Wyższej Szkoty Zarządzania i Przedsiębiorczości z siedzibą w Wałbrzychu" 2016, nr 38(2), s. 117-128.

Ponomarenko T., Zinchenko O., Khudoliei V., Prokopenko O., Pawliszczy D., Formation of the investment environment in Ukraine in the context of European integration: An example of Poland, „Investment Management and Financial Innovations” 2018, vol. 15(1), s. 361-373.

Rutkowska M., Zielone miejsca pracy jako ecoinnowacja, „Zeszyt Naukowy Wyższej Szkoły Zarządzania i Bankowości w Krakowie" 2016, nr 39, s. 151-161, http://bazekon.icm.edu.pl /bazekon/element/bwmeta1.element.ekon-element-000171433926 (dostęp: 2.06.2020).

Ryszawska B., Zielona gospodarka - teoretyczne podstawy koncepcji i pomiar jej wdrażania w Unii Europejskiej, Wydawnictwo Uniwersytetu Ekonomicznego we Wrocławiu, Wrocław 2013.

Sobol A., Uwarunkowania rozwoju rynku dóbri usług ekologicznych w gminach województwa ślqskiego, „Studia Ekonomiczne. Zeszyty Naukowe Uniwersytetu Ekonomicznego w Katowicach" 2015, nr 232, s. 225-236, http://bazekon.icm.edu.pl/bazekon/element/bwmeta1.ele ment.ekon-element-000171396763 (dostęp: 3.06.2020).

Stańczyk-Hugiet E., Charakterystyka relacji, [w:] J. Niemczyk, E. Stańczyk-Hugiet, B. Jasiński (red.), Sieci międzyorganizacyjne. Współczesne wyzwanie dla teorii i praktyki zarzq̨dzania, Wydawnictwo C.H. Beck, Warszawa 2012, s. 25-34.

Stańczyk-Hugiet E., Lichtarski J.M., Piórkowska K., The Dynamics of Inter-firm Relationships along the Industry Life Cycle: Theoretical Background and Conceptual Framework, „Transformations in Business Economics" 2019, no. 18(2B (47B)), s. 767-782.

Stańczyk-Hugiet E., Piórkowska K., Stańczyk S., Strużyna J., Evolutionary Selection Processes. Towards Intra-Organizational Facets, Emerald Publishing, Bingley 2019.

Stańczyk S., Tożsamość ekosystemu biznesu, Wydawnictwo Uniwersytetu Ekonomicznego we Wroctawiu, Wroctaw 2018.

Sulich A., Rola zielonego zarządzania w równoważeniu rynku pracy, praca doktorska, Politechnika Wroctawska, Wroctaw 2019.

Sulich A., Zema T., Green jobs, a new measure of public management and sustainable development, „European Journal of Environmental Sciences” 2018, vol. 8(1), s. 69-75.

Ustawa z dnia 20 grudnia 1996 r. o gospodarce komunalnej (Dz.U. z 1997 r. Nr 9, poz. 43).

Ustawa z dnia 11 maja 2001 r. o obowiązkach przedsiębiorców w zakresie gospodarowania niektórymi odpadami oraz o opłacie produktowej (Dz.U. z 2018 r., poz. 1932).

Wirth U., Abductive reasoning in Peirce's and Davidson's account of interpretation, „Semiotica” 2005, vol. 153, no. 1/4, s. 199-208, https://doi.org/10.1515/semi.2005.2005.153-1-4.199 (dostęp: 2.06.2020).

Zema T., Sulich A., Relations in The Interorganizational Networks, vol. 6, 4th International Business Administrative Sciences Student Conference - IBASSC 2019, Erbil, Irak 2019. 


\section{Streszczenie}

Problemy dotyczące równowagi stosunków między działalnością człowieka a środowiskiem są szczególnie widoczne w sektorze dóbr i usług środowiskowych. Istnieją w nim sieci międzyorganizacyjne, oparte na procesach recyklingu, oczyszczania, rekultywacji oraz na świadczeniu usług komunalnych. Sieci te mogą mieć charakter operacyjny lub nadzorczo-kontrolny. W opracowaniu przedstawiono studium przypadku sieci operacyjnej dedykowanej recyklingowi, przetwarzaniu i gospodarowaniu poużytkowymi odpadami, jakimi są opony. Praca ma charakter założeń teoretycznych i operacjonalizacji pojęć dla badania empirycznego, które będzie kontynuacją prowadzonego projektu analizy relacji w wybranym sektorze.

Słowa kluczowe: ekosystem biznesu, sieć międzyorganizacyjna, zielone miejsca pracy

\section{Inter-organizational network case study in the environmental goods and services sector}

\section{Abstract}

Problems related to the balance of relations between human activities and the natural environment are particularly visible in the environmental goods and services sector. There are inter-organizational networks in this sector based on recycling, treatment, reclamation processes and the provision of municipal services. These networks can be operational or supervisory-control. The paper presents a case study of a network dedicated to recycling, processing and management of post-consumer waste, such as tires. The work has the character of theoretical assumptions and operationalization of concepts for empirical research, which will be a continuation of the ongoing project of relationships analysis in a selected sector.

Keywords: green jobs, inter-organizational network 